\title{
What Attracted Keynes to Malthus's High Price of Provisions?
}

\author{
Nobuhiko Nakazawa \\ Kansai University
}

\begin{abstract}
In his biographical essay on Malthus, Keynes highly praised Malthus's early short pamphlet, High Price of Provisions. Yet there have been remarkably few commentators who have paid attention to High Price of Provisions; and fewer have taken notice of two underlying but importantly related problems hidden in Keynes's analysis of this pamphlet. This paper attempts to resolve these problems by providing a more comprehensive explanation for Keynes's discussion of High Price of Provisions than Keynes himself. Not only does this paper reinforce the idea that Keynes discovered the concept of effective demand by reading Malthus, but it further proposes that Keynes would have seen other parallels between himself and Malthus, including their methods of approaching practical economic problems.
\end{abstract}

Keywords: John Maynard Keynes, Thomas Robert Malthus, effective demand, poverty, unemployment

JEL Classification: B12, B22, B31, B41, E12

This paper reconstructs and extends one part of John Maynard Keynes's discussion in his biographical essay on Malthus (1972). It is widely known that Keynes praised Thomas Robert Malthus for helping to inspire his own theory of effective demand. Although this subject has been dealt with in many articles and books, the depth and range of Keynes's debt to Malthus is complex and continues to elicit controversy. In his long essay on Malthus, found in Essays in Biography (1933), Keynes highly praised Malthus's early short pamphlet, High Price of Provisions (1800), as "one of the best things Malthus ever wrote" (1972, 90). Yet, as I will show, there are remarkably few commentators who

AUTHOR's NoTE: I am grateful to many who commented on drafts of this paper or provided other indispensable help, particularly Atsushi Komine, Matthew Smith, John Pullen, Michael Paton and especially Rod O'Donnell. I would also like to thank the journal editors and reviewers for detailed critiques that greatly improved this paper. Part of this study was supported by JSPS KAKENHI Grant Number 2525066 and 15H03332. Responsibility for the remaining errors lies with me. 
have taken notice of Malthus's High Price of Provisions; and even fewer have noticed the two underlying important problems hidden in Keynes's analysis of this pamphlet.

One probable reason for this neglect is that there is little prima facie evidence for a direct link between Malthus's pamphlet and Keynes's own work. First, in High Price of Provisions, Malthus attributed the present economic distress and depression to a lack of supply relative to demand in the provisions market. In addressing this state of affairs, Malthus expresses himself like a microeconomic analyst utilising a traditional demand-and-supply approach to the economy, which contrasts sharply with Keynes's macroeconomic approach. Second, Keynes claimed that he highly valued the High Price of Provisions primarily because the pamphlet contained statements that connected effective demand, prices and profits. ${ }^{1}$ In reality, however, there is no mention of effective demand and profit in Keynes's quotations from High Price of Provisions. Nonetheless, there are important links between Malthus's article and Keynes's work of the mid-1930s, as this article will demonstrate.

The subject of Keynes's indebtedness to Malthus has given rise to a large and continually expanding literature; ${ }^{2}$ but no authoritative literature on this subject has specifically addressed Keynes's evaluation of High Price of Provisions. ${ }^{3}$ One could point to some important exceptions, but none of them manages to fully resolve the relation between Malthus's article and Keynes's work. ${ }^{4}$ This paper attempts to

\footnotetext{
${ }^{1}$ These two problems ultimately boil down to a single problem: In what sense, and to what extent, did Malthus anticipate Keynes?

${ }^{2}$ A partial list of the authoritative literature on this subject includes Black (1986), Blaug (1958, 238-240), Corry (1986), Cottrell (1998), Dostaler (2007, 180-182), Fitzgibbons (1988, 13-16, 195-197), Guthrie (1984), Hollander (1986; 1996), Kates (1994; 1998, Chap. 7; 2008; 2010), Klein (1966, 124-130), Lambert (1986), Petersen (1955; 1999, 82-99, 146-147), Pullen (2001), Rutherford (1987), and Skidelsky (1992, 410-417, 464-465).

${ }^{3}$ For a detailed account of Malthus's discussion in High Price of Provisions and the historical background of this pamphlet, see Bonar (1924, 48-49, 307, 415-422), Hollander (1997, 225-226), James (1979, 79-92), Johnson (1986, 59), Turner (1986, 120124), Wells (1988, 7-10), Winch (1987, 44; 1996, 270), and Wrigley (1999), none of whom mention Keynes's reading of this pamphlet.

${ }^{4}$ Noted among them are Carabelli (2003, 217), Hirai (2008, 100-102), O'Donnell (2006, 399-400), O'Leary (1986, 99-100), and Sen (1981, Appendix B; 1994, 75). They did give ample attention to Keynes's approving discussion of High Price of Provisions in which the concept of effective demand was to be found. O'Leary (1986) and O'Donnell (2006) explained, but did not analyse this point. By focusing on economic methodology but not on effective demand, Carabelli (2003) made the brief, but interesting, suggestion that "Keynes's interpretation of Malthus's more mature writings (particular $A n$ Investigation of the Causes of the Present High Price of Provisions (1800) and his
} 
make clear the precise nature of this relation by providing a more comprehensive analysis for Keynes's discussion of High Price of Provisions than his own. To this end, it introduces a missing quotation in his discussion.

This paper not only reinforces the idea that Malthus set Keynes on the path to develop the theory of effective demand, but-given Malthus's distinction between types of poverty in High Price of Provisions - it also argues that it is likely that Keynes would have seen other remarkable parallels between himself and Malthus.

It would be beyond the scope of this paper to give a full treatment of the issue that Keynes tried to express in his essay on Malthus. I hope, however, to offer evidence to support the claim that we can add High Price of Provisions to the collection of Malthus's writings that inspired Keynes's ideas. Furthermore, I suggest that the research in this paper is

correspondence with Ricardo) introduces aspects which, in my view, tend to reflect Keynes's own approach more than Malthus's" $(2003,217)$. Through study of Malthus's 1800 pamphlet and his correspondence with Ricardo, Hirai (2008) stressed that Keynes as author of Essays in Biography had still been living in the world of the Treatise on Money (1930), not yet completely moving into that of the General Theory (1936), and therefore concluded that the direct influence of Malthus on Keynes's thinking was rather limited. Regarding the similarity between Malthus's and Keynes's discussions on effective demand, Hirai negatively noted that: "Keynes does not use the term 'effective demand' in the same sense as Malthus does" (2008, 101). However, it seems to me that this was not the essential issue to Keynes. As will be discussed in more detail in the remainder of this introductory section and the third and fourth sections, it would be better to think that Keynes's acknowledgement of Malthus's pioneering contribution in the matter of effective demand was not made in terms of pure economic theories but broader economic visions. My own view supports Steven Kates's following assessment: "That Malthus had a different theory of deficient 'effective demand' than Keynes would ultimately develop is not really germane. What Keynes takes from Malthus is the desire to demonstrate the importance of effective demand and therefore to refute Say's Law. This is the critical issue" (1994, 18). Amartya Sen critically examined High Price of Provisions and discussed its contribution to Sen's own 'entitlement approach' to starvation and famines, while bearing in mind that his theory of effective demand in this pamphlet was very attractive to Keynes. Sen stated: "Interesting enough, while Malthus had tended to concentrate rather wholeheartedly on the rhetoric of the proportion between the natural increase of population and food' in his Essay on population, in his other works he was very acutely concerned with the role of effective demand and incentives in the operation of the economy. In fact, Keynes's [...] great praise of Malthus [...] was related specifically to Malthus's analysis of 'effective demand'. This side of Malthusian economic analysis is also well illustrated by his deeply illuminating essay, An investigation of the cause of the present high price of provisions" $(1994,75)$. Sen could also draw interesting lessons on poverty reduction efforts from Malthus's analysis in High Price of Provisions, while keeping in mind the causation of the Bengal famine in 1943. However, his main message is that the problem of famines is about food access rather than food supply, which therefore contradicts Malthus's basic argument that famines are caused by the natural tendency of a population to outrun its subsistence. 
helpful to our understanding of the contemporary relevance of earlier economic insights in poverty reduction.

A few preliminaries are in order. With regard to the extent of Keynes's debt to Malthus, I do not accept the clear theoretical contrast between Keynes's macroeconomic approach and Malthus's microeconomic one as the complete story; I regard their methodological and epistemological similarities as essential. With regard to the concept of effective demand, therefore, my inquiry is not concerned with a theoretical-level analysis (such as the so-called unemployment equilibrium). Instead, it is concerned with what might be called 'cognitive-level' analysis: it investigates what inspired Keynes to develop the idea that lack of demand is the principal problem of a falling economy. To borrow Toye's turn of phrase, what I am exploring here is Malthus as an "inspirer", not a "precursor", of Keynes (2000, 192). ${ }^{5}$ To speak more generally in Schumpeter's terms, I am focused in this paper on "Vision" as "a pre-analytic cognitive act that supplies the raw material for the analytic effort" $(1954,41)$.

The paper is organised as follows. Section I provides the reader with an overview of Malthus's High Price of Provisions. Sections II and III deal with Keynes's reading of the pamphlet, and the last section summarises the main arguments.

\section{Malthus's High Price of Provisions}

Before examining Keynes's discussion of Malthus's High Price of Provisions in his biographical essay (Keynes 1972), it is helpful to begin by dealing with the core claim of this relatively neglected early pamphlet.

In 1800, High Price of Provisions was published as Malthus's second work. Its full title was, An Investigation of the Cause of the

\footnotetext{
${ }^{5}$ No one can initiate an analytic effort without first grasping a rough image of the problems to be tackled. In this respect, there is a critical difference between a precursor (or a forerunner) and an inspirer. Was Malthus the precursor or the inspirer of Keynes? As explained below, I believe he was the latter. It is worth noting that statements, such as "Malthus was not in fact an analytic forerunner of Keynes" (Corry 1986, 76) or "Malthus was not really tackling the same problem as Keynes or using the same tools" (Black 1986, 248), merely deny the direct theoretical influence of Malthus on Keynes, and do not include the idea that Keynes derived a profound inspiration from Malthus. The critical suspicion that Keynes might have been strategising and attempting to find enemies of Ricardo to support his case does not recognise the essential methodological and epistemological level and thus, for the same reason as before, seems to miss the target.
} 
Present High Price of Provisions, Containing an Illustration of the Nature and Limits of Fair Price in Time of Scarcity, and Its Application to the Particular Circumstances of this Country. The economic setting for the pamphlet was the widespread scarcity of grain in 1799-1800. Previously, on a recent visit to Sweden, Malthus observed a bad harvest. After discovering food shortages upon his return to Britain, he noticed the price of daily necessities had increased to a higher level than could be explained merely from the degree of scarcity. His concern was that a proper understanding of the principles of the market's operation was absent. The task which he set for himself in the pamphlet was not to uncover why the price of provisions had been high, but why it had been abnormally high when accounting for their availability. He wrote this pamphlet in only two days and printed it for the meeting of Parliament on 11 November, 1800. He hoped to enlighten Parliament and influence policy (1897).

Following Adam Smith (Book 4, Digression on Corn, of the Wealth of Nations), Malthus argued against the out-dated and ignorant explanation that the greed of agricultural middlemen caused the extremely high price of provisions:

The continuation of extraordinary high prices, after a harvest that was at one time looked forward to as abundant, has contributed still more to astonish and perplex the public mind. Many men of sense have joined in the universal cry of the common people, that there must be roguery somewhere; and the general indignation has fallen upon monopolisers, forestallers, and regraters [...].

I ought first to premise, however, that I am not interested in this question, further than as a lover of truth, and a well-wisher to my country. I have no sort of connection whatever with any of these middle men or great farmers, who are now the objects of public indignation: and, as an individual with a small fixed income, I am certainly among that class of persons on whom the high price of provisions must fall the heaviest $(1986,6){ }^{6}$

\footnotetext{
${ }^{6}$ Food rioters in the eighteenth and early nineteenth centuries were far from mere unorganised mobs. They were disciplined crowds in pursuit of clear objectives shared by the community. Powerfully informed by a sense of traditional rights and customs, they wished to express legitimate protest against injustice and misrule (such as market manipulation by middlemen or agents) and demanded a fair or just price for the goods. This is the so-called 'moral economy'. See, for example, Porter (1990, 12, 190191) and Thompson (1991, Chaps. 4-5). Additionally, as a matter of course, the views Smith and Malthus held about the functions of middlemen in trade is a different issue from the historical correctness and fairness of their views.
} 
So, what was the principal cause of the extremely high price of provisions? Malthus conjectured that "the system of poor laws and parish allowances" generated the upward pressure on prices $(1986,8){ }^{7}$ This system created an inflationary effect.

In explaining how prices had risen, Malthus referred to Adam Smith's price theory (Book 1, Chap. 6, of the Wealth of Nations). However, Malthus was not a mere follower and interpreter of Smith, for he contended that Smith's discussion on natural and market prices should be modified in times of acute scarcity:

Adam Smith has most justly stated, that the actual price at which a commodity is sold, is compounded of its natural price, the price at which it can be brought to market, allowing the usual profit in times of moderate plenty, and the proportion of the supply to the demand. When any commodity is scarce, its natural price is necessarily forgotten, and its actual price is regulated by the excess of the demand above the supply $(1986,7)$.

Malthus's own explanation centred on the short-term market pricewhat Malthus called the "actual price"-not on the natural price, ${ }^{8}$ in contrast to Smith's stress on the market price's long-term tendency to

\footnotetext{
${ }^{7}$ The English (old) poor laws from the late eighteenth century up to the Poor Law Amendment Act of 1834 are known as the so-called 'Speenhamland system' of providing parish allowances to workers who received wages below what was considered a subsistence level.

${ }^{8}$ Malthus's explanation of natural price in the High Price of Provisions - "the price at which it [a commodity] can be brought to market" $(1986,7)$-is very sketchy and not clear enough. Unfortunately, further discussion of it is not discernible anywhere else in this pamphlet. His entire treatment of natural price can be found in Principles of Political Economy (1820), where he elaborated in a manner loyal to Adam Smith: "[...] the price of any exchangeable commodity, may be considered as consisting of three parts-that which pays the wages of the labourer employed in its production; that which pays the profits of capital by which such production has been facilitated; and that which pays the rent of land [...]. / The price which fulfils these conditions is precisely what Adam Smith calls the natural price. [...] It [the definition of necessary price] will be, the price necessary, in the actual circumstances of the society, to bring the commodity regularly to the market. This is only a shorter description of what Adam Smith means by natural price, as contradistinguished from market price or the price at which commodities actually sell in the market, which [...] are sometimes sold higher and sometimes lower than the price which is necessary to fulfil the conditions of a regular supply" (1989, Vol. 1, 82-83). This long quotation shows that Malthus's definition of natural price basically followed the definition given by Smith.
} 
gravitate to the natural price. " "When any commodity is scarce" its market price exceeds its natural price. Malthus inferred that the market price of corn was raised by the parish allowance system "beyond" what the ordinary forces of demand and supply would have generated under conditions of acute scarcity. He stated (Quote M1):

I am most strongly inclined to suspect, that the attempt in most parts of the kingdom to increase the parish allowances in proportion to the price of corn, combined with the riches of the country, which have enabled it to proceed as far as it has done in this attempt, is, comparatively speaking, the sole cause, which has occasioned the price of provisions in this country to rise so much higher than the degree of scarcity would seem to warrant, so much higher than it would do in any other country where this cause did not operate [...].

Let us suppose a commodity in great request by fifty people, but of which, from some failure in its production, there is only sufficient to supply forty. If the fortieth man from the top have two shillings which he can spend in this commodity, and the thirty nine above him, more, in various proportions, and the ten below, all less, the actual price of the article, according to the genuine principles of trade, will be two shillings [...] (1986, 6-7).

Malthus imagined a ranking of the various demand prices-what we would today call a demand schedule-of fifty individuals for one unit of corn. When a reduction in total supply from fifty to forty units permitted only the top forty consumers to remain in the market, Malthus maintained that the market price of a unit of corn should reflect the demand price of the fortieth consumer, or in other words, should be determined by the purchasing power of the marginal consumer. He subsequently stated (Quote M2):

Let us suppose, now, that somebody gives the ten poor men, who were excluded, a shilling apiece. The whole fifty can now offer two shillings, the price which was before asked. According to every genuine principle of fair trading, the commodity must immediately rise. If it do not, I would ask, upon what principle are ten, out of the fifty who are all able to offer two shillings, to be rejected? For still, according to the supposition, there is only enough for forty. The two

\footnotetext{
${ }^{9}$ Henceforth in this paper, when I refer to "the short-term" and "the long-term", I will mean historical (or real) time, not logical (or analytical) time (for instance, Alfred Marshall's four time periods).
} 
shillings of a poor man are just as good as the two shillings of a rich one; and, if we interfere to prevent the commodity from rising out of the reach of the poorest ten, whoever they may be, we must toss up, draw lots, raffle, or fight, to determine who are to be excluded. It would be beyond my present purpose, to enter into the question whether any of these modes would be more eligible, for the distribution of the commodities of a country, than the sordid distinction of money; but certainly, according to the customs of all civilized and enlightened nations, and according to every acknowledged principle of commercial dealing, the price must be allowed to rise to that point which will put it beyond the power of ten out of the fifty to purchase. This point will, perhaps, be half a crown or more, which will now become the price of the commodity. Let another shilling apiece be given to the excluded ten: all will now be able to offer half a crown. The price must in consequence immediately rise to three shillings or more, and so on toties quoties. (1986, 7-8)

Quotes M1 and M2 clearly illustrate the effect that the system of poor laws and parish allowances had on food prices. In Malthus's diagnosis, the excessive rise in food prices was a result of a higher level of expenditure which reflected the transfer of income from rich to poor. ${ }^{10}$

In the following two sections, I will focus how Keynes interpreted Malthus's 1800 pamphlet.

\section{How did Keynes ReAd Malthus's High Price of Provisions?}

Let us now critically examine Keynes's discussion of Malthus's High Price of Provisions. That Keynes highly praised Malthus as his intellectual predecessor should not escape the informed reader. In his 1933 essay on Malthus, Keynes lamented that "the almost total obliteration of Malthus's line of approach and the complete domination of Ricardo's for a period of a hundred years has been a disaster to the progress of economics" $(1972,98)$; he thus paid great tribute to Malthus, an amiable critic of the orthodox and abstract political economy approach originated by his friend and intellectual rival Ricardo. The following quotation is well known: "If only Malthus, instead of Ricardo,

\footnotetext{
${ }^{10}$ As will be argued again near the end of section II, the corn market is no ordinary market. Corn is also an input into another commodity consumed by the masses (such as beer). An induced rise in the price of corn is widely effective on other markets' prices and hence can be called inflationary.
} 
had been the parent stem from which nineteenth-century economics proceeded, what a much wiser and richer place the world would be today!" (1972, 100-101). It is worth noting that, among Malthus's many writings, High Price of Provisions was especially praised by Keynes. As he wrote in his biographical essay on Malthus (Quote K1):

Meanwhile Malthus had continued his economic studies with a pamphlet, published anonymously (like the first edition of the Essay [on the Principles of Population]) in 1800, entitled An investigation of the cause of the present high price of provisions. This pamphlet has importance both in itself and as showing that Malthus was already disposed to a certain line of approach in handling practical economic problems which he was to develop later on in his correspondence with Ricardo,- - a method which to me is most sympathetic, and, as I think, more likely to lead to right conclusions than the alternative approach of Ricardo. [...].

According to Malthus's good common-sense notion prices and profits are primarily determined by something which he described, though none too clearly, as 'effective demand' [...]. Ricardo, in the course of simplifying the many successive stages of his highly abstract argument, departed, necessarily and more than he himself was aware, away from the actual facts; whereas Malthus, by taking up the tale much nearer its conclusion, had a firmer hold on what may be expected to happen in the real world [...].

Malthus's conception of 'effective demand' is brilliantly illustrated in this early pamphlet [...]. He was pondering why the price of provisions should have risen by so much more than could be accounted for by any deficiency in the harvest [...]. He found the cause in the increase in working-class incomes as a consequence of parish allowances being raised in proportion to the cost of living. (1972, 87-89, italics in original, underlining added $)^{11}$

Having written this, Keynes quoted M1 and M2 from High Price of Provisions, which he saw as excellent illustrations of Malthus's approach

\footnotetext{
${ }^{11}$ According to John Toye's historical investigation (2000, 44, 190-191), Keynes's 1912 Cambridge lecture notes on the supply of labour are the earliest version of what became his 1933 essay on Malthus. He continued to expand and modify it (not necessarily regularly), but the final major changes were made between October 1932 and January 1933, when he was in the initial stages of the theorising that would lead, nearly three years later, to the publishing of the General Theory. It was during this period that he added many new passages relating to High Price of Provisions as well as Malthus's economic theory and his intellectual relationship with Ricardo. See also Clarke (1988, 266-267).
} 
to effective demand. However, Keynes added "though none too clearly", for Malthus himself did not use this term in M1 and M2. Nevertheless, Keynes found in them the concept of effective demand, even if only as a pre-analytic cognitive act. It should be noted here in relation to the later stage of discussion that what we now call an outwards shift of the demand curve in a particular market, which was induced by the increase in working-class incomes, was suggestive of the increase of effective demand in Keynes (1933). Following this long citation, he continues (Quote K2):

The words and the ideas are simple. But here is the beginning of systematic economic thinking. There is much else in the pamphletalmost the whole of it-which would bear quotation. This Investigation [of the Cause of the Present High Price of Provisions] is one of the best things Malthus ever wrote [...]. (1972, 89-90)

Why did Keynes value High Price of Provisions so highly? His remarks are too vague to tell us what he really meant by them. As has already been mentioned, there are two underlying but importantly related problems hidden here. The first problem arises from the fact that Malthus addressed the issue of the extremely high price of provisions from the standpoint of the shortage of supply over demand. This traditional supply-and-demand approach stands in sharp contrast to Keynes's focus on the general excess of productive power over the level of demand. The second problem is that, curiously and surprisingly, in both M1 and M2, Malthus was silent on the topic of profit, while he tried to articulate the process by which the poor-relief system generated the upward pressure on prices through raising the purchasing power of the poor. There is no reference to profit in either M1 or M2, from which Keynes concluded that "prices and profits are primarily determined by [...] 'effective demand'” $(1972,88)$. This absence seems strange and worthy of further inquiry.

I will examine both problems in greater detail, starting with the second one. If we take Keynes's words literally, where and how did Malthus discuss the topic of profit? Curiously again, this topic was discussed in the second half of High Price of Provisions, where Malthus espoused short-term advantageous results of the English poor laws in contrast to his full attack on them in the first Essay on the Principles of Population (1798) as the following quotation (M3) indicates: 
I do not, however, by any means, intend to infer, from what I have said, that the parish allowances have been prejudicial to the state; or that, as far as the system has been hitherto pursued, or is likely to be pursued, in this country, that it is not one of the best modes of relief that the circumstances of the case will admit. The system of the poor laws, in general, I certainly do most heartily condemn, as I have expressed in another place [the first Essay on the Principles of Population], but I am inclined to think that their operation in the present scarcity has been advantageous to the country. The principal benefit which they have produced, is exactly that which is most bitterly complained of-the high price of all the necessaries of life. The poor cry out loudly at this price; but, in so doing, they are very little aware of what they are about; for it has undoubtedly been owing to this price that a much greater number of them has not been starved.

It was calculated that there were only two thirds of an average crop last year. Probably, even with the aid of all that we imported, the deficiency still remained a fifth or sixth. Supposing ten millions of people in the island; the whole of this deficiency, had things been left to their natural course, would have fallen almost exclusively on two, or perhaps three millions of the poorest inhabitants, a very considerable number of whom must in consequence have starved. The operation of the parish allowances, by raising the price of provisions so high, caused the distress to be divided among five or six millions, perhaps, instead of two or three, and to be by no means unfelt even by the remainder of the population [...].

The further effects of the high price have been to enforce a strict economy in all ranks of life; to encourage an extraordinary importation, and to animate the farmer by the powerful motive of self interest to make every exertion to obtain as great a crop as possible the next year. $(1986,13-14)$

Here Malthus stated how farmers would behave when faced with an increase in the nominal price of food. As is clear from his comments on profits, this statement seems very helpful in endorsing a more sophisticated interpretation for Keynes's discussion of High Price of Provisions.

Although M3 is not included in Essays in Biography, there is little doubt that Keynes was aware of M3, given K2: "There is much else in the pamphlet-almost the whole of it-which would bear quotation" (1972, 
89-90). ${ }^{12}$ I contend that M3 is worthy of particular attention because it is very insightful not only in explaining Malthus's ideas about profitmotivated farmers' behaviours, but also in conveying quite different views on poverty and the poor laws system from those in the first Essay on the Principles of Population.

How much and how quickly, then, was the additional demand for food expected to increase food production? In the first Essay on the Principles of Population, Malthus assumed price fixity-or, extremely low elasticity-of food supply in the short-term, while perceiving the longterm sequence of events that is shown by such a stream as 'population growth', 'increased effective demand for food', 'an increase in the nominal prices of food', 'an increase of capital and labour input in the food production sector', and 'an increase of food production'. His analysis of the unfavourable consequences of the English Poor Laws rested on this strong assumption (Winch, 1987, 43). He bitterly argued against the system of poor laws and parish allowances as encouraging working-class population growth without increasing the food supply, thereby raising prices, lowering real wages, and spreading poverty to a larger section of the lower classes. There is no doubt that Malthus remained a strong advocate of the (gradual) abolition of the poor law system throughout his life. ${ }^{13}$

By contrast, however, in High Price of Provisions - in particular in M3-Malthus focused on the advantageous short-term results of the poor law system. Now let us carefully analyse Malthus's short-run and long-run evaluations of the system, which were rooted in his important distinction of the 'two types of poverty'. He did not unconditionally attribute poverty to personal irresponsibility, but made a sharp distinction between (1) the poverty brought on by idleness, folly, and lack of foresight, and (2) the poverty caused by misfortune or by circumstances beyond one's control (Winch 1987, 42; Masunaga 2011, 94). ${ }^{14}$ The poverty caused by scarcity or by unemployment after the

\footnotetext{
${ }^{12}$ The fact that Keynes did not quote M3 does not mean that he was unaware of it, just that he merely failed to be fully explicit on profits. In other words, I am not suggesting that he lacked logical coherence, for he was writing a biographical essay, not a step-bystep formal dissertation.

${ }^{13}$ Malthus added to the 1817 edition of Essay on the Principles of Population: "What I really proposed is [...] the gradual and very gradual abolition of the poor laws" (1989, Vol. 1, 374, italics in original). See also Winch $(1987,48)$ and $(1996,270)$.

${ }^{14}$ Historically less government interference and greater personal responsibility have constituted the core beliefs of conservatism. With this in mind, we need to suspend Malthus's certificate of qualification as a conservative thinker in spite of his well-
} 
sudden end of war-generated demand is placed in the second category of poverty, to which the principle of personal responsibility is not applicable. It follows that public assistance should be provided for those in need. Presumably guided by this distinction, Malthus could claim that the operation of parish allowances had benefited the whole community during the famine of that time (Smith 2001, 412-414; Winch 1987, 44; 1996, 270, 307; Wrigley and Souden 1986, 36-37).

Malthus's diagnosis shows that extremely high food prices, led by the allowance system, not only mitigated some particular individual misfortune by spreading the burden over a larger number of people (Sen 1981, Appendix B; Wrigley 1999), but also gave profit-motivated farmers an incentive to increase the crop of next year. He asserted that the allowance system could be justified on humanitarian grounds, and that the high price of provisions was effective in making farmers increase food production in the next period in return for higher expected profits and income. ${ }^{15}$ In opposition to the framework of Ricardo's theory, in which higher food prices led to higher monetary wages and lower profits, Malthus argued that higher food prices, presumably reflecting the higher marginal propensity of the poor to consume owing to the allowance system, made higher profits for farmers in the next period possible by increasing the demand for their products. M3 is a vital statement for our understanding of the function of profit in High Price of Provisions.

It is true that as the author of High Price of Provisions, Malthus is only dealing with one market-and, hence, partial equilibrium analysis in modern terms. However, this market is no ordinary market because it has huge significance for the bulk of the consuming population as well as many producers. So whatever happens in this particular market has widespread consequences for most of society. These effects are thus not just partial or limited, but widespread and hence virtually macroeconomic or societal in scale. Their widespread nature may have inspired Keynes to shift the ideas of rising demand due to higher

known attacks on the French Revolution in the first Essay on the Principles of Population.

${ }^{15}$ In this respect, therefore, it would be an over-simplified, inaccurate, and unfair assessment of Malthus's thought to conclude that: "Over the years, family allowances have been criticized for promoting population growth, for increasing tax burdens because of the need to finance these benefits, and for lowering wage rates. Malthus [...] was the first and main opponent of aid to the poor because of its impact on population growth. Many have followed this road hewn by Malthus" (Pressman, 2014, 522). 
incomes, followed by rising prices, in turn followed by increased supply induced by higher profits, to the macro stage. ${ }^{16}$

Now, at last, we have arrived at the point where the previous discussion can throw additional light on why Keynes highly valued High Price of Provisions. The principal reasons would seem to be twofold: (1) because Malthus's emphasis on the demand side as the primary driving force of the economy in this pamphlet paralleled Keynes's indication that demand was the primary determinant of the level of output as opposed to Say's Law which emphasised supply and the impossibility of demand deficiencies; (2) because it anticipated Keynes's vision of the possibilities for economic policy to combat the (involuntary) mass unemployment in interwar Britain. ${ }^{17}$ For Keynes, Malthus was right in regarding a lack of demand as the major cause of the distress and hardships of the poor. Since they were not responsible for their own poverty, they were not responsible for reducing it either. For Keynes, Malthus was also right in admitting that some forms of government intervention such as the parish allowances in proportion to the price of corn were effective in the short-run reduction of poverty. Thus, it would be legitimate to suggest that there is an intriguing parallel between Malthus's distinction of two types of poverty and Keynes's distinction of the two types of unemployment: (1) voluntary and (2) involuntary. ${ }^{18}$

Moreover, pamphlets usually primarily seek to persuade the reader on a topic of current interest, and so it is natural for their authors to concentrate their interests on short-term issues. ${ }^{19}$ As such, High Price of

\footnotetext{
${ }^{16}$ If the higher marginal propensity of the poor to consume is brought into this story, it strengthens the initial rise in demand, but the story still works even if the rich and poor had the same marginal propensity to consume.

${ }^{17}$ My discussion here basically follows that of Steven Kates: "That Malthus had a different theory of deficient 'effective demand' than Keynes would ultimately develop is not really germane. What Keynes takes from Malthus is the desire to demonstrate the importance of effective demand and therefore to refute Say's Law. This is the critical issue; it is Keynes's determination to refute Say's Law which becomes the central theme of the General theory" (1994, 18; see also Kates 1998, 143). In this excellent paper, Kates persuasively argues that Keynes actually arrived at his central idea as a consequence of reading the Malthus side of the Malthus-Ricardo correspondence whilst revising his biographical essay on Malthus in late 1932. However, my argument is that High Price of Provisions is also important in this story.

${ }^{18}$ As Alan Coddington rightly commented: "To say that someone is involuntarily unemployed is to relieve him of the responsibility for his condition; it is to suggest that he is unemployed 'through no fault of his own'” $(1983,27)$.

${ }^{19}$ Keynes himself was in favour of publishing pamphlets on particular subjects, and in fact many of his essays were originally written as pamphlets. He wrote in his famous obituary to Alfred Marshall: "Economists must leave to Adam Smith alone the glory of the quarto, must pluck the day, fling pamphlets into the wind, write always sub specie
} 
Provisions was designed to investigate the short-term causality between increased effective demand and increased food production-a Malthusian "line of approach in handling practical economic problems" (Keynes 1972, 87), which therefore never "departed [...] away from the actual facts" (88) that the poor were starving in the short-term rather than in the long-term (Winch, 1987, 44). Given the above, there should be little doubt that Keynes could find some significant parallels other than effective demand between himself and Malthus while he was reading High Price of Provisions.

It should be kept in mind, however, that all of the above interpretations are reasonable but hypothetical. It is irrefutable that Keynes did not quote M3 from High Price of Provisions, and no one can give an exact answer to the question of how Keynes read M3. Moreover, it is also unquestionably true that there was a fundamental difference between Malthus's and Keynes's economics when it comes to the theoretical framework used.

\section{How did Keynes ReAd Malthus's High Price of Provisions? -Continued}

Here we arrive at the first of those two problems. Malthus attributed the distress and depression of his time to a lack of supply relative to demand in the provisions market, whereas Keynes attributed them in the 1930s to the general excess of productive power over the level of demand. Malthus's approach is microeconomic, while Keynes's is macroeconomic. However, this does not mean that Keynes's debt to Malthus is based on flimsy grounds, much less that we should accept Takashi Negishi's $(1989 ; 1993)$ remarkable interpretation of Malthus as rather a non-Keynesian (or, more polemically, an anti-Keynesian), "supply-side economist who emphasized the motives to produce as a function of the rate of profit" $(1989,139 ; 1993,116) .^{20}$ I think that such an interpretation of Malthus has gone too far and that it can be

temporis, and achieve immortality by accident, if at all" (1972, 199). See also O'Donnell (2006).

${ }^{20}$ Following Negishi's view that "Malthus is not so much an underconsumptionist as a supply sider" (1989, 152), Heinz Kurz commented: "Keynes's view of Malthus and the classical economists is difficult to sustain. Negishi is right in arguing that Malthus was not a precursor of Keynes, but despite appearances to the contrary, 'a supply-side economist who emphasized the motives to produce as a function of the rate of profit'" $(2011,357)$. 
subsumed to a considerable extent within a more comprehensive interpretation, such as that provided by John Pullen. ${ }^{21}$

Malthus must have considered that the high price of grain was caused by the interaction of demand and supply. For he wrote specifically that: "When any commodity is scare [...] its actual price is regulated by the excess of the demand above the supply" (Malthus, 1986, 7). Following Pullen, therefore, I would interpret him as a demandand-supply economist than a supply-side economist. Meanwhile, it should also be noted that Negishi's comments were made merely in terms of pure economic theories but not in terms of their broader economic implications. This suggests, conversely, that we should not reject, but actually accept, that Keynes's vision of the possibilities for economic policy had much in common with that of Malthus.

What attracted Keynes to Malthus's High Price of Provisions can be summed up as follows: (1) an alternative approach to economic policy from the abstract approach of Ricardian orthodoxy; (2) the broad principles that lack of demand, not supply, is the principal problem of a falling economy and that income redistribution in favour of the poor contributes to an increase in effective demand; and (3) the idea that public assistance can be legitimately provided for those in need due to causes for which they are not responsible. These ideas are not only those that Keynes thought Malthus "was to develop later on in his correspondence with Ricardo" (1972, 87), but are also those that were much later to become key premises in Keynes's 1936 book. In the General Theory, Keynes wrote: "in the later phase of Malthus the notion of the insufficiency of effective demand takes a definite place as a scientific explanation of unemployment" (1973, 362-363), with long citations of letters from Malthus to Ricardo, dated 7 July, 1821, and 16 July, 1821, as well as of Malthus's Principles of Political Economy (1820).

By focusing on the concept of effective demand, the two great economists agreed on a common "line of approach in handling practical

\footnotetext{
${ }^{21}$ Pullen insightfully pointed out that: "In accordance with his 'doctrine of proportions' he [Malthus] attempted to formulate a system in which the forces of demand and supply are kept in balance. He recognised that economic growth would be impeded as much by a lack of saving, capital and investment as by a lack of consumption and demand. His intention was to complement the growth theory of Smith by redressing the balance between demand-side causes of growth and the supply-side causes" (1993, 15). For a detailed account of Malthus's doctrine of proportions, see Pullen (1982). It should also be noted that Pullen stressed the importance of supply in Malthus's theory from the point of view of his multi-causal methodology. For this, see Pullen (2001).
} 
economic problems" (Keynes 1972, 87), such as the following: 'A change in demand leads to a change in supply' and 'redistribution of income in favour of the poor causes an increase in production at less than full employment'. These are, for Keynes, nothing but "what may be expected to happen in the real world" $(1972,88)$.

\section{CONCLUSION}

In this paper, I have made an attempt to resolve the two underlying but importantly related problems hidden in Keynes's interpretation of Malthus's High Price of Provisions. As for the first problem, relating to Malthus's traditional demand-and-supply approach to the economy, while admitting a fundamental difference in the theoretical framework between Malthus's and Keynes's economics, I have postulated that Malthus and Keynes shared the idea that demand preceded supply, their approaches to practical economic problems and their economic visions of the possibilities for economic policy. As for the second, relating to Keynes's seemingly mysterious treatment of Malthus's High Price of Provisions, I have offered a more comprehensive explanation for it than Keynes himself did by introducing a relevant quotation (M3) into the discussion. Malthus's understanding of the expected profit depending on the current effective demand provided a significant clue in investigating the development of Keynes's economic ideas in the General Theory and the need for suitable policies in the face of the mass unemployment in interwar Britain. Certain economic ideas espoused by Malthus's High Price of Provisions, particularly those relating to the short-run, may have inspired Keynes more than his explicit statements in 1933 indicate. The Malthus who received Keynes's praise was the Malthus who made much of a short-term-causality-focused approach to practical economic problems - which, to borrow Keynes's own words, we might call an approach to "the actual facts" in "the real world" (1972, 88). ${ }^{22}$

These results throw helpful light on the relevance of our economic discussion on poverty reduction. The question of what causes poverty is still debated today, and there is no simple answer. At least, however, the fact that the two great economists commonly treated poverty and

\footnotetext{
${ }^{22}$ At the same time, however, we should be cautious in order not to take on faith "a Keynesianised Malthus that ignored Malthus's own concern with long-term growth prospects as well as short-term adjustment problems" (Winch 1996, 27, italics in original). See also Winch $(1987,93)$.
} 
unemployment as partially involuntary phenomena should make us question explanations which blame poverty on individuals and their idleness. It should also encourage us to refrain from over-applying or abusing the principle of personal responsibility respecting poverty and unemployment, which mirrors overconfidence in the working of the market.

My final suggestion to those interested in understanding the indebtedness of Keynes to Malthus, in several areas, is to not overlook High Price of Provisions.

\section{REFERENCES}

Black, R. D. Collison. 1986 [1967]. "Parson Malthus, the General and the Captain." In Thomas Robert Malthus: Critical Assessments, edited by John Cunningham Wood, vol. 1, 244-259. London: Croom Heim.

Blaug, Mark. 1958. Ricardian Economics: A Historical Study. New Haven: Yale University Press.

Bonar, James. 1924. Malthus and His Work. Second edition. London: George Allen and Unwin.

Carabelli, Anna. 2003. "Keynes: Economics as a Branch of Probable Logic." In The Philosophy of Keynes's Economics: Probability, Uncertainty and Convention, edited by Jochen Runde and Sohei Mizuhara, 216-226. London and New York: Routledge.

Clarke, Peter. 1988. The Keynesian Revolution in the Making 1924-1936. Oxford: Clarendon Press.

Coddington, Alan. 1983. Keynesian Economics: The Search for First Principles. London: George Allen and Unwin.

Corry, Bernard. A. 1986 [1959]. "Malthus and Keynes-A Reconsideration." In Thomas Robert Malthus: Critical Assessments, edited by John Cunningham Wood, vol. 4, 7583. London: Croom Heim.

Cottrell, Allin. 1998. "Keynes, Ricardo, Malthus and Say's Law." In Keynes and the Classics Reconsidered, edited by James C. W. Ahiakpor, 63-75. Boston and London: Kluwer Academic.

Dostaler, Gilles. 2007. Keynes and His Battles. Cheltenham: Edward Elgar.

Fitzgibbons, Athol. 1988. Keynes's Vision: A New Political Economy. Oxford: Clarendon Press.

Guthrie, William G. 1984. "Selective Discovery of Economic Ideas: What Keynes Found in Malthus." Southern Economic Journal 50 (3): 771-780.

Hirai, Toshiaki. 2008. Keynes's Theoretical Development: From the Tract to the General Theory. London and New York: Routledge.

Hollander, Samuel. 1986 [1962]. "Malthus and Keynes: A Note." In Thomas Robert Malthus: Critical Assessments, edited by John Cunningham Wood, vol. 1, 217-222. London: Croom Heim.

Hollander, Samuel. 1996. "Keynes and Malthus: On Some Recent Secondary Literature." History of Economics Review 25: 127-128.

Hollander, Samuel. 1997. The Economics of Thomas Robert Malthus. Toronto: University of Toronto Press. 
James, Patricia. 1979. Population Malthus: His Life and Times. London: Routledge and Kegan Paul.

Johnson, Harry G. 1986 [1949]. "Malthus on the High Price of Provisions." In Thomas Robert Malthus: Critical Assessments, edited by John Cunningham Wood, vol. 4, 5972. London: Croom Heim.

Kates, Steven. 1994. "The Malthusian Origins of the General Theory or How Keynes Came to Write a Book about Say's Law and Effective Demand." History of Economics Review 21: 10-20.

Kates, Steven. 1998. Say's Law and the Keynesian Revolution: How Macroeconomic Theory Lost Its Way. Cheltenham and Northampton: Edward Elgar.

Kates, Steven. 2008. "A Letter from Keynes to Harlan McCracken Dated 31st August 1933: Why the Standard Story on the Origins of the General Theory Needs to be Rewritten." History of Economics Review 47: 39-53.

Kates, Steven. 2010. "Influencing Keynes: The Intellectual Origins of the General Theory." History of Economic Ideas XVIII (3): 33-64.

Keynes, John Maynard. 1972 [1933]. "Thomas Robert Malthus: The First of the Cambridge Economists." In The Collected Writings of John Maynard Keynes, vol. 10, 71-103. London: Macmillan for the Royal Economic Society.

Keynes, John Maynard. 1973 [1936]. The General Theory of Employment, Interest and Money. In The Collected Writings of John Maynard Keynes, vol. 7. London: Macmillan for the Royal Economic Society.

Klein, Lawrence R. 1966. The Keynesian Revolution. Second edition. New York: Macmillan.

Kurz, Heinz D. 2011. "The Contributions of Two Eminent Japanese Scholars to the Development of Economic Theory: Michio Morishima and Takashi Negishi." In The Dissemination of Economic Ideas, edited by Heinz D. Kurz, Tamotsu Nishizawa and Keith Tribe, 337-364. Cheltenham and Northampton: Edward Elgar.

Lambert, Paul. 1986 [1966]. "Lauderdale, Malthus and Keynes." In Thomas Robert Malthus: Critical Assessments, edited by John Cunningham Wood, vol. 1, 223-243. London: Croom Heim.

Malthus, Thomas Robert. 1897 [1800]. “A Letter of Malthus to Rev. George Turner.” Economic Journal 7 (26): 271-272.

Malthus, Thomas Robert. 1986 [1800]. "An Investigation of the Cause of the Present High Price of Provisions." In The Works of Thomas Robert Malthus, edited by Edward Anthony Wrigley and David Souden, vol. 7, 5-18. London: William Pickering.

Malthus, Thomas Robert. 1989 [1803-1826]. An Essay on the Principles of Population, edited by Patricia James, 2 volumes. Cambridge: Cambridge University Press.

Malthus, Thomas Robert. 1989 [1820-1836]. Principles of Political Economy, edited by John Pullen, 2 volumes. Cambridge: Cambridge University Press.

Masunaga, Atsushi. 2011. "Malthus's Ideas on Poor Relief: The Principle of Temporary Relief and Its Practical Basis." In Poverty and Welfare in Economic Thought: Theories on 'Governing Society and Providing Relief to the People' in Modern Japan and Britain, edited by Atsushi Komine, 64-97. Kyoto: Minerva Shobo (in Japanese).

Negishi, Takashi. 1989. History of Economic Theory. Amsterdam, New York, Oxford, and Tokyo: North-Holland. 
Negishi, Takashi. 1993. "A Smithian-Growth Model and Malthus's Optimal Propensity to Save." The European Journal of the History of Economic Thought 1 (1): 115-127.

O'Donnell, Roderick M. 2006. "Keynes's Principles of Writing (Innovative) Economics." The Economic Record 82 (259): 396-407.

O'Leary, James J. 1986 [1942]. "Malthus and Keynes." In Thomas Robert Malthus: Critical Assessments, edited by John Cunningham Wood, vol. 1, 90-104. London: Croom Heim.

Petersen, William. 1955. "John Maynard Keynes's Theories of Population and the Concept of 'Optimum'.” Population Studies 8 (3): 228-246.

Petersen, William. 1999 [1979]. Malthus: Founder of Modern Demography. New Brunswick: Transaction Publishers.

Porter, Roy. 1990. English Society in the Eighteenth Century. Revised edition. London: Penguin Books.

Pressman, Steven. 2014. "Keynes, Family Allowance, and Keynesian Economic Policy." Review of Keynesian Economics 2 (4): 508-526.

Pullen, John. 1982. "Malthus on the Doctrine of Proportions and the Concept of the Optimum." Australian Economic Papers 21: 270-285

Pullen, John. 1993. "Malthus and Adam Smith." The Bulletin of the Matsudaira Memorial Institute, Kanto Gakuen University 10: 1-28.

Pullen, John. 2001. “Keynes's Criticisms of Malthus, and 'Malthus's Reply': The Concept of Effective Supply." History of Economics Review 34: 168-181.

Rutherford, Robert Peter. 1987. "Malthus and Keynes." Oxford Economic Papers 39 (1): 175-189.

Schumpeter, Joseph Alois. 1954. History of Economic Analysis. New York: Oxford University Press.

Sen, Amartya. 1981. Poverty and Famines: An Essay on Entitlement and Deprivation. Oxford: Clarendon Press.

Sen, Amartya. 1994. "Population and Reasoned Agency: Food, Fertility, and Economic Development." In Population, Economic Development, and the Environment, edited by Kerstin Lindahl Kiessling and Hans Landberg, 51-78. Oxford: Oxford University Press.

Skidelsky, Robert. 1992. John Maynard Keynes: The Economist as Saviour 1920-1937. London: Macmillan.

Smith, Adam. The Wealth of Nations. London: Penguin Books.

Smith, Richard M. 2001. "Welfare of the Individual and the Group: Malthus and Externalities." Proceedings of the American Philosophical Society 145 (4): 402-414.

Thompson, Edward Palmer. 1991. Customs in Common. London: Merlin Press.

Toye, John. 2000. Keynes on Population. Oxford: Oxford University Press.

Turner, Michael. 1986. "Corn Crisis in Britain in the Age of Malthus." In Malthus and His Time, edited by Michael Turner, 112-128. London: Macmillan.

Wells, Roger. 1998. Wretched Faces: Famine in Wartime England 1793-1802. New York: St. Martin's Press.

Winch, Donald. 1987. Malthus-Past Masters. Oxford: Oxford University Press.

Winch, Donald. 1996. Riches and Poverty: An Intellectual History of Political Economy in Britain, 1750-1834. Cambridge: Cambridge University Press.

Wrigley, Edward Anthony. 1999. "Corn and Crisis: Malthus on the High Price of Provisions." Population and Development Review 25 (1): 121-128. 
Wrigley, Edward Anthony, and David Souden. 1986. "Introduction." In The Works of Thomas Robert Malthus, edited by Edward Anthony Wrigley and David Souden, vol. 1, 7-39. London: William Pickering.

Nobuhiko Nakazawa is Professor of History of Economic Thought at Kansai University, Japan, where he has taught since 1998. His research interests lie in the fields of history of economic thought and methodology, particularly issues relating to Edmund Burke, Thomas Robert Malthus and British conservatism. He is former president of the Japanese Society of Malthus (2009-2011). He has published papers in journals such as Modern Age and History of Economics Review.

Contact e-mail: <nakazawa@kansai-u.ac.jp> 